Portland State University

PDXScholar

$11-2021$

\title{
Data from: "Developing Strategies to Enhance Mobility and Accessibility for Community-Dwelling Older Adults"
}

\author{
Kate Hyun \\ University of Texas at Arlington \\ Kathy Lee \\ University of Texas at Arlington \\ Caroline Krejci \\ University of Texas at Arlington
}

Follow this and additional works at: https://pdxscholar.library.pdx.edu/trec_data

Part of the Transportation Commons, Urban Studies Commons, and the Urban Studies and Planning Commons

Let us know how access to this document benefits you.

\section{Recommended Citation}

Hyun, Kate, Lee, Kathy, Caroline, Krejci, Oran Gibson, Nilufer and Saha, Troyee, Data from: Developing Strategies to Enhance Mobility and Accessibility for Community-Dwelling Older Adults. NITC 1304. Portland, OR: Transportation Research and Education Center (TREC), 2021. https://doi.org/10.15760/ TREC_datasets. 17

This Dataset is brought to you for free and open access. It has been accepted for inclusion in TREC Datasets and Databases by an authorized administrator of PDXScholar. Please contact us if we can make this document more accessible: pdxscholar@pdx.edu. 


\begin{tabular}{|l|l|}
\hline ID & [Researcher only $] \quad 46$ \\
\hline Date &
\end{tabular}

\section{Transportation}

1. How many times do you usually travel each week using the following modes of transportation? * Please leave it empty if not applicable. (If you drive twice a day for five days a week, your total would be 10 times a week.)

1-1. Drive ( 1 times a week)

1-2. Have others drive you ( $h$ times a week)

1-3. Walk ( times a week)

1-4. Bike (

1-5. Public transportation (times a week)

1-6. Taxi or cab (

1-7. Ridesharing services including Uber/Lyft ( _

1-8. Special transportation services, such as one for older adults or persons with disabilities

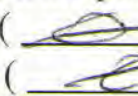
times a week)

1-9. Others times a week)

2. Please indicate your average time you spent for each trip.

2-1. Drive ( $\angle O$ minutes per each trip)

2-2. Have others drive you ( 5 minutes per each trip)

2-3. Walk (

2-4. Bike ( minutes per each trip)

2-5. Public transportation (_ minutes per each trip)

2-6. Taxi or cab ( minutes per each trip)

2-7. Ridesharing services including Uber/Lyft ( minutes per each trip)

2-8. Special transportation services, such as one for older adults or persons with disabilities minutes per each trip)

2-9. Others minutes per each trip)

3. Currently, do you have a car?

由Yes a No

4. If you currently don't have a car, did you previously have a car?

\Yes $\square$ No

4-1. If you no longer drive, why not? * Please check all that apply.

$\square_{4}$ Health reasons

$\square_{3}$ Financial reasons

$\square_{2}$ No necessity

$\square_{1}$ Other (please explain):

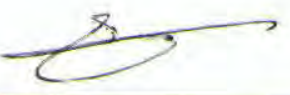


4-2 If you no longer drive, how independent do you still feel in your daily life?

$\square_{\text {s }}$ Extremely independent

$a_{4}$ Very independent

$\square_{3}$ Somewhat independent

$\square_{2}$ Not very independent

$\square_{1}$ Not at all independent

5. How important are different transportation services for you to be able to live independently in your neighborhood as you age? * Please check " $\mathrm{X}$ " in one box for each service.

\begin{tabular}{|l|l|l|l|l|l|}
\hline & $\begin{array}{l}\text { Extremely } \\
\text { important }\end{array}$ & $\begin{array}{l}\text { Very } \\
\text { important }\end{array}$ & $\begin{array}{l}\text { Somewhat } \\
\text { important }\end{array}$ & $\begin{array}{l}\text { Not very } \\
\text { important }\end{array}$ & $\begin{array}{l}\text { Not at all } \\
\text { important }\end{array}$ \\
\hline $\begin{array}{l}\text { Public transportation (e.g., } \\
\text { bus, trains) }\end{array}$ & & & & \\
\hline $\begin{array}{l}\text { Special transportation for } \\
\text { older adults or persons } \\
\text { with disabilities (e.g., } \\
\text { Handitran, Dart Ride) }\end{array}$ & & & & & \\
\hline Have others drive you & & & & & \\
\hline Walk/bike & & & & & \\
\hline Taxi or cab & & & & \\
\hline $\begin{array}{l}\text { Ridesharing service } \\
\text { (Uber/Lyft) }\end{array}$ & & & & & \\
\hline $\begin{array}{l}\text { Well-lit and safe streets } \\
\text { \& intersections for all } \\
\text { users (i.e., pedestrians, } \\
\text { bicyclists, drivers) }\end{array}$ & & & & & \\
\hline $\begin{array}{l}\text { Audio/visual aids for a } \\
\text { signalized intersection or } \\
\text { a 4 way stop }\end{array}$ & & & & & \\
\hline $\begin{array}{l}\text { Driver education/training/ } \\
\text { driver refresher courses }\end{array}$ & & & & & \\
\hline
\end{tabular}

6. Which transportation services do you have or do you wish to have in your neighborhood?

* Please check " $\mathrm{X}$ " in one box for each service.

\begin{tabular}{|l|l|l|l|l|}
\hline & $\begin{array}{l}\text { Currently } \\
\text { available }\end{array}$ & $\begin{array}{l}\text { Not } \\
\text { available } \\
\text { but needed }\end{array}$ & $\begin{array}{l}\text { Not } \\
\text { available } \\
\text { nor needed }\end{array}$ & $\begin{array}{l}\text { I do not } \\
\text { know }\end{array}$ \\
\hline $\begin{array}{l}\text { Public transportation (e.g., bus, } \\
\text { trains) }\end{array}$ & & & & \\
\hline $\begin{array}{l}\text { Special transportation for older adults } \\
\text { or persons with disabilities }\end{array}$ & & & & \\
\hline Taxi or cab & & & & \\
\hline
\end{tabular}


7. Please rank your preferred modes in order of transportation to get around for activities for essentials (e.g., grocery shopping)? ("1" indicates the most preferred mode and "7" indicates the least preferred mode.)

\begin{tabular}{|l|l|}
\hline & Rank $\left(17^{7}\right)$ \\
\hline Drive yourself & \\
\hline Public transportation (e.g., bus, trains) & \\
\hline Special transportation for older adults or persons with disabilities & \\
\hline Have others drive you & \\
\hline Walk/bike & \\
\hline Taxi or cab & \\
\hline Ridesharing service (e.g., Uber/Lyft) & \\
\hline
\end{tabular}

8. What are your preferred modes in order of transportation to get around for health care activities (e.g., visiting the doctor)? ("1" indicates the most preferred mode and "7" indicates the least preferred mode.)

\begin{tabular}{|l|l|}
\hline & Rank $(1-7)$ \\
\hline Drive yourself & \\
\hline Public transportation (e.g., bus, trains) & \\
\hline Special transportation for older adults or persons with disabilities & \\
\hline Have others drive you & \\
\hline Walk/bike & \\
\hline Taxi or cab & \\
\hline Ridesharing service (e.g., Uber/Lyft) & \\
\hline
\end{tabular}

9. What are your preferred modes in order of transportation to get around for productive activities (e.g., working and volunteering)? (" 1 " indicates the most preferred mode and "7" indicates the least preferred mode.)

\begin{tabular}{|l|l|}
\hline & Rank $(1-7)$ \\
\hline Drive yourself & \\
\hline Public transportation (e.g., bus, trains) & \\
\hline Special transportation for older adults or persons with disabilities & \\
\hline Have others drive you & \\
\hline Walk/bike & \\
\hline Taxi or cab & \\
\hline Ridesharing service (Uber/Lyft) & \\
\hline
\end{tabular}


10. What are your preferred modes in order of transportation to get around for social activities (e.g., visiting friends or going to a senior center)? (" 1 " indicates the most preferred mode and "7" indicates the least preferred mode.)

\begin{tabular}{|l|l|}
\hline & Rank $(\boldsymbol{h}-7)$ \\
\hline Drive yourself & \\
\hline Public transportation (e.g., bus, trains) & \\
\hline Special transportation for older adults or persons with disabilities & \\
\hline Have others drive you & \\
\hline Walk/bike & \\
\hline Taxi or cab & \\
\hline Ridesharing service (e.g., Uber/Lyft) & \\
\hline
\end{tabular}

11. How many times did you miss each activity over the past month due to insufficient transportation options? * Please indicate " 0 " if you did not miss any activity.

11-1. Essentials (e.g., grocery shopping) 11-2. Doctor appointment __ times missing this trip 11-3. Social participation/events (e.g., community centers, libraries, and religious organizations) times missing this trip 11-4. Job and/or volunteer work times missing this trip

11-5. Health/recreational activity (e.g., gym) times missing this trip 11-6. Others (Please specify: 8 times missing this trip

12. How satisfied are you with transportation services that you have used? * Please check " $X$ " in one box for each service.

\begin{tabular}{|c|c|c|c|c|c|}
\hline & $\begin{array}{l}\text { Extremely } \\
\text { satisfied }\end{array}$ & $\begin{array}{l}\text { Very } \\
\text { satisfied }\end{array}$ & $\begin{array}{l}\text { Somewhat } \\
\text { Satisfied }\end{array}$ & $\begin{array}{l}\text { Not very } \\
\text { satisfied }\end{array}$ & $\begin{array}{l}\text { Not } \\
\text { applicable }\end{array}$ \\
\hline $\begin{array}{l}\text { Public transportation } \\
\text { (e.g., bus, trains) }\end{array}$ & & & & & \\
\hline $\begin{array}{l}\text { Special transportation for } \\
\text { older adults or persons } \\
\text { with disabilities }\end{array}$ & & & & & \\
\hline Walk/bike & & & & & \\
\hline Taxi or cab & & 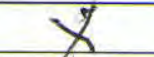 & & & \\
\hline $\begin{array}{l}\text { Ridesharing service (e.g., } \\
\text { Uber/Lyft) }\end{array}$ & & 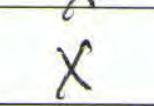 & & & \\
\hline
\end{tabular}


12-1. If you are not satisfied with public transportation, why? * Please skip this question if you are satisfied with public transportation. * Please check all that apply.

$\square_{6}$ I am satisfied with the service

$\square_{5}$ Safety concerns

$\square_{4}$ Cost (affordability)

$\square_{3}$ Inadequate schedule or frequency or not available in my neighborhood

$\square_{2}$ Don't know how to use it.

Other please specify):

12-2. If you are not satisfied with special transportation (e.g., Handitran, Dart Ride), why? * Please skip this question if you are satisfied with special transportation. * Please check all that apply.

$\square_{6}$ I am satisfied with the service

口. Safety concerns

$\square_{4}$ Cost (affordability)

$\square_{3}$ Inadequate schedule or frequency or not available in my neighborhood

$\square_{2}$ Don't know how to use it.

$\square_{1}$ Other please specify):

12-3. If you are not satisfied with rideshare services, why? $*$ Please skip this question if you are satisfied with rideshare services. * Please check all that apply.

$\square_{6}$ I am satisfied with the service

$\square_{5}$ Safety concerns

$\square_{4}$ Cost (affordability)

$\square_{3}$ Inadequate schedule or frequency or not available in my neighborhood

$\square_{2}$ Don't know how to use it.

\&Other please specify):

12-4. If you are not satisfied with taxi/cab services, why? * Please skip this question if you are satisfied with taxi/cab services. * Please check all that apply.

$\square_{6}$ I am satisfied with the service

$\square_{5}$ Safety concerns

$\square_{4}$ Cost (affordability)

$\square_{3}$ Inadequate schedule or frequency or not available in my neighborhood

$\square_{2}$,Don't know how to use it.

$\$ 1$ Other please specify):

12-5. If you are not satisfied with walk/bike service/environment, why? * Please skip this question if you are satisfied with taxi/cab services. * Please check all that apply.

$\square_{6}$ I am satisfied with the service

$\square_{5}$ Safety concerns (I do not feel safe for neighborhoods that I walk.)

$\square_{4}$ No facilities (No sidewalks or bike lanes)

$\square_{2} /$ cannot walk or bike to my destination because it is too far.

. Other please specify): 


\section{Information}

13. To enhance your mobility, what are your greatest needs? Please indicate the rank in order (" 1 " indicates the most need and " 6 " indicates the least need.)

\begin{tabular}{|l|c|}
\hline & Rank (1-6) \\
\hline Public transportation service (bus, trains) & \\
\hline City/community public transportation service for older adults (e.g., van-pool) & \\
\hline Financial assistance for existing ride-sharing service (Uber and Lyft) or taxi/cab & $\times$ \\
\hline Assistance with technology (e.g., install an app, open a credit card) & \\
\hline Assistance with trip scheduling & \\
\hline $\begin{array}{l}\text { Provide travel partners (someone accompanied with you for travel) for ride- } \\
\text { sharing (Uber/Lyft) or taxi/cab }\end{array}$ & \\
\hline
\end{tabular}

14. How familiar are you with information about different transportation services in your communify, such as community van-pool or special transportation for older adults?
$\square_{5}$ Extremely familiar
$\square_{4}$ Very familiar
$\square_{3}$ Somewhat familiar
$\square_{2}$ Not very familiar
$\square_{1}$ Not at all familiar

15. If you needed information about transportation options/services, how likely is it that you would use the following resources? * Please check " $\mathrm{X}$ " in one box for each service.

\begin{tabular}{|l|l|l|l|l|l|}
\hline & $\begin{array}{l}\text { Extremely } \\
\text { likely }\end{array}$ & Very likely & $\begin{array}{l}\text { Somewhat } \\
\text { likely }\end{array}$ & $\begin{array}{l}\text { Not very } \\
\text { likely }\end{array}$ & $\begin{array}{l}\text { Not at all } \\
\text { likely }\end{array}$ \\
\hline $\begin{array}{l}\text { Local aging } \\
\text { organizations (e.g., } \\
\text { senior centers, area } \\
\text { agencies on aging, etc.) }\end{array}$ & V & & & & \\
\hline $\begin{array}{l}\text { Transportation providers } \\
\text { (e.g., DART, Uber/Lyft, } \\
\text { etc, }\end{array}$ & V & & & & \\
\hline $\begin{array}{l}\text { Faith-based organizations } \\
\text { (e.g., churches or } \\
\text { synagogues) }\end{array}$ & & & & & \\
\hline Internet & & & & & \\
\hline $\begin{array}{l}\text { Your doctor or other } \\
\text { health care professional }\end{array}$ & & & & & \\
\hline AARP & & & & & \\
\hline Phone book & & & & & \\
\hline Family members & & & & & \\
\hline Friends/Neighbors & & & & & \\
\hline
\end{tabular}


16. In general, how often do you go online to access the Internet for activities/information related to transportation? For instance: securing a shared ride (Uber, Lyft, etc), obtaining information related to DART bus services, or arranging for ride share programs. This includes access from home, work, a mobile device (such as a smartphone), or someplace else.
$\square_{7}$ Several times a day
$\square_{6}$ About once a day
$\square_{5}$ 3-6 times a week
$\square_{4}$ 1-2 times a week
$\square_{3}$ Once every few weeks
$\square_{2}$ Once a month or less
$\square_{1}$ Never go online

16-1. Is there anything that may be improved to provide better accommodations for your transportation usage?

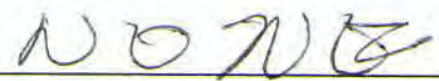

16-2. If you use online services to secure transportation, how did you learn of these services?

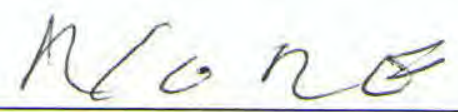

16-3. If you do not use online services to secure transportation, why not? Is there anything that prevents you from going online to secure transportation? (for example: no internet, no credit card, difficulty speaking/reading English, unable to use smartphone, fear of driving with a stranger, lack of handicap accessible options?)

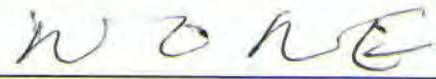

\section{Health and Well-being}

17. Thinking about your mobility - ability to walk, which one describes you the best?

$\square_{3}$ I am able to walk more than $1 / 4$ mile.

$\square_{2}$ I have some difficulty with mobility. I can only walk less than $1 / 4$ miles at once.

$\square_{1}$ I have a lot of difficulty with mobility. I need someone to help me

18. In general, when compared with most people your age, how would you rate your health?
$\square_{5}$ Excellent
$\square_{4}$ Very good

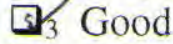
$\square_{2}$ Fair
$\square_{1}$ Poor 
19. How often do you feel socially isolated?

$\square_{5}$ Not at all

$\square_{4}$ Rarely

$\square \square_{3}$ Sometimes

$\square_{2}$ Offen

D. Always

About You

1. Are you male or female?

$\square_{1}$ Male

प1. Female

2. How old are you?

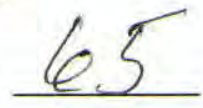

3. What is your current marital status?

$\square_{1} \quad$ Married or living with a partner

D2 Separated or divorced

$\square$ Widowed

$\square_{4} \quad$ Single, never married

4. Besides yourself, do you have any of the following people living in your household?
a. Child/children under 18 .
Yes $/$ No
b. Child/children 18 or older
Q $\square_{2}$
c. Parents
$\square_{1} \quad \square_{2}$
d. Other adult relative or friend 18 or older ....... $\quad \square_{1} \quad \square_{2}$

$\square$ 回 $\square_{2}$

5. Are you of Hispanic, Spanish, Latino origin or descent?

Yes 7 No

6. What is your race and/or ethnicity? * Please check all that apply.
$\square_{1}$, White or Caucasian
$\square_{2}$ Black or African American
$\square$ American Indian or Alaska Native
$\square$ Asian
$\square$ Native Hawaiian or other Pacific Islander
$\square$ Other, please specify:

7. Is there adlanguage other than English spoken in your home?

(If yes, please indicate: 
8. What is the highest level of education you have completed?

D. $\mathrm{K}-12^{\text {th }}$ grade (no diploma)

$\square_{2} \quad$ High school graduate, GED or equivalent

$\square_{3}$ Post-high school education/training (no degree)

$\square_{4} \quad 2$ year college degree

$\square_{5} 4$ year colleage degree

$\square_{6}$ Post-graduate study / Graduate or professional degrees

9. What was your annual household income before taxes in the most recent tax year?
(1) Less than $\$ 10,000$
$\square_{5} \$ 50,000$ to $\$ 74,999$
$\square_{2} \quad \$ 10,000$ to $\$ 19,999$
$\square_{6} \quad \$ 75,000$ to $\$ 99,999$
$\square_{3} \$ 20,000$ to $\$ 29,999$
$\square_{7} \quad \$ 100,000$ to $\$ 149,999$
$\square_{4} \$ 30,000$ to $\$ 49,999$
$\square_{8} \quad \$ 150,000$ or more

$\square_{5} \$ 50,000$ to $\$ 74,999$

10. How do you describe your employment status? * Please check all that apply.

$\begin{array}{ll}\square_{1} & \text { Full-time employed } \\ \square_{2} & \text { Part-time employed } \\ \square_{3} & \text { Out or work and looking for work } \\ \square_{4} & \text { Out of work but not currently looking for work } \\ \square_{5} & \text { A homemaker } \\ \square_{6} & \text { Retired } \\ \square_{7} & \text { Prefer not to answer }\end{array}$

